\title{
Phytochemical parameters and antioxidant activity of new cherry silverberry biotypes (Elaeagnus multiflora Thunb.)
}

\author{
Sabina Lachowicz ${ }^{1} \cdot$ Anna Bieniek $^{2} \cdot$ Zygmunt Gil $^{1} \cdot$ Natalia Bielska $^{2} \cdot$ Bogumił Markuszewski $^{2}$
}

Received: 10 April 2019 / Revised: 31 May 2019 / Accepted: 9 June 2019 / Published online: 15 June 2019

(c) The Author(s) 2019

\begin{abstract}
This paper analyses the phytochemical composition, and antioxidant activity of new selected biotypes of cherry silverberry grown in Poland. In addition, the polyphenolic contents, sugars, and vitamin C, as well as organic acid profile were evaluated. Among the researched compounds, two sugars, seven organic acids, and six fatty acids were reported in new studied biotypes of cherry silverberry. Some new biotypes presented a high contents of vitamin C, linoleic, $\alpha$-linoleic acids (si1, and si2), glucose, fructose, ash (si5, and si4), other fatty acids, organic acids, and antioxidant activity (si0, and si3). They displayed an average contents of polyphenols [5.68 g GAE/100 g dry matter (d.m.)], vitamin C (15.13 mg/100 g), ash (0.56\%), fatty acids (89.99\%), organic acids (22.41 g/100 g d.m.), sugars (47.96 g/100 g d.m.), and high antioxidant activity of $3.62 \mathrm{mM}$ Trolox (TE)/100 g d.m. (FRAP assay), and $5.11 \mathrm{mM} \mathrm{TE} / 100 \mathrm{~g}$ d.m. (DPPH assay). The new biotypes of cherry silverberry cultivated in Poland might be a good source for the production of functional foods, and direct consumption. Moreover, cherry silverberry is an inquisitive material with a different phytochemical components, and according to the principal component analysis, strongly dependent on the biotype.
\end{abstract}

Keywords Fruit $\cdot$ Cherry silverberry $\cdot$ Vitamin C $\cdot$ Polyphenols $\cdot$ Acid profiles $\cdot$ PCA

\section{Introduction}

The search for plant species that are a source of bioactive substances is an important subject of research by scientists from many research centers around the world. Consumers are also looking for tasty, natural foods produced in an uncontaminated environment. Particular attention is paid to less-known plants growing in various climatic zones, and then introduced to cultivation outside their natural origin [1]. Plants that meet these criteria include Far Eastern species, especially those from the Elaeagnaceae family, which are gaining increasing popularity. The genus Elaeagnus includes

Sabina Lachowicz

sabina.lachowicz@upwr.edu.pl

Anna Bieniek

anna.bieniek@uwm.edu.pl

1 Department of Fermentation and Cereals Technology, Wrocław University of Environmental and Life Science, 37 Chełmońskiego Street, 51-630 Wrocław, Poland

2 Deprtment of Horticulture, University of Warmia and Mazury in Olsztyn, 21 Prawocheńskiego Street, 10-720 Olsztyn, Poland about 70-80 plant species [2, 3]. Despite numerous representatives of this type, only a few species have been thoroughly examined, including $E$. angustifolia (narrow-leaved cherry silverberry), E. umbellata (mother-earthen cherry silverberry), and E. multiflora (cherry silverberry, gumi) which is not fully understood. Phytochemical assessment studies have shown that the fruits of Elaeagnus genus plants contain numerous chemical compounds that can positively affect human health. Studies have shown that the fruits of these plants contain, among others, phenolic acids (chlorogenic; caffeic; $p$-formic acids), flavonoids (routine, quercetin), lipids, carotenoids, ascorbic acid, and a significant amount of lycopene [2]. Research has confirmed that these compounds have antioxidant (primarily anti-cancer) properties. Anti-cancer activity has been confirmed by experiments on in vitro as well as in vivo models. The causes of tumor-suppressing properties are sought for the ability to remove reactive oxygen species, interfere with cell division, and modulate the signal transduction pathway. Lee et al. [4], also showed that the multiflorous cherry silverberry (Elaeagnus multiflora) in its composition has a number of chemical compounds-secondary metabolites that affect health. These compounds occur in various parts of plants. It was 
found that the fruit of the cherry silverberry contains a number of carotenoids, while its leaves are characterized by a high content of sugar, fatty acids, and phytosterols.

In addition, the cherry silverberry is a native plant to China, Korea and Japan. This is a shrub growing up to $3 \mathrm{~m}$. The fruits are ellipsoidal, of a drupe-like type, up to $1-\mathrm{cm}$ long, and are set on stems. Their color is red, and they are juicy, and sour, with a taste resembling that of red currant. In Poland, silverberries ripen at the end of June or at the beginning of July [5]. In China, cherry silverberry, generally referred to as gumi, has been known as a medicinal plant, traditionally used as a remedy for couch, diarrhea, itch, and foul sores, and even cancer [6]. Fruits of this plant can be used in home processing to prepare juice, compote, jam, and other food products [7]. This species is currently being introduced into cultivation in Russia, Ukraine, and USA, while it has not yet been commercially produced in Poland. Since the 1990s, research has been carried out at the Department of Horticulture of the University of Warmia and Mazury in Olsztyn to select the best forms for introduction into cultivation in Poland. The assessment of the yield, morphology, and quality of the fruit of the four biotypes of the long-leaved cherry silverberry in terms of their suitability for cultivation in the conditions of north-eastern Poland was presented by Bieniek et al. [5].

According to the available literature [8,9], fruits of the cherry silverberry contain carbohydrates, pectins, and acids. In addition, there are lipids in the fruit of the cherry silverberry along with dissolved sterols, vitamins, and mineral compounds. Such diversity of chemical components in the fruit of the cherry silverberry causes that nutritional and dietary value is also attributed to them [4, 10-12].

Therefore, the aim of this work was to evaluate the phytochemicals profile analysis by HPLC, and antioxidant activity (DPPH, and FRAP assay) of new selected biotypes of cherry silverberry grown in Poland. An additional goal was to select the most valuable fruits in terms of chemical composition, and promote fruits little known to the food industry. Furthermore, the PCA system was used to show the important dependences between the biotypes of cherry silverberry, and the tested phytochemical composition.

\section{Materials and methods}

\section{Reagent and standard}

Acetonitrile, formic acid, methanol, DPPH (1,1-diphenyl2-picrylhydrazyl radical), 6-hydroxy-2,5,7,8-tetramethylchroman-2-carboxylic acid (Trolox), 2,4,6-tri(2-pyridyl)-striazine (TPTZ), methanol acetic acid, and phloroglucinol were purchased from Sigma-Aldrich (Steinheim, Germany). Gallic acid was purchased from Extrasynthese (Lyon,
France). Analytic standards of tartaric acid, citric acid, malic acid, lactic acid, succinic acid, fructose, glucose were purchased from Dr. Ehrenstrofer (Teddington, UK). Acetonitrile (HPLC gradient grade), and sulphuric acid (analytical grade) were purchased from POCH (Gliwice, Poland). Formic acid (LC-MS grade) was purchased from Fischer Scientific (Schwerte, Germany). Acetonitrile for ultra-phase liquid chromatography (UPLC; Gradient grade), and ascorbic acid were obtained from Merck (Darmstadt, Germany).

\section{Plant materials}

The experiment was established in 2007 in the Experimental Garden of the University of Warmia and Mazury in Olsztyn (north-eastern Poland, latitude: $53^{\circ} 50 \mathrm{~N}, 20^{\circ} 31 \mathrm{E}$ ). Fruit samples $(\sim 10.0 \mathrm{~kg}$ each) were collected at the optimum ripening time in 2018 (in the same time). The climate of Olsztyn is typical for lakeland areas, determined by local elements of the environment, i.e., the land form, and numerous lakes, and forests. The study involved three vegetatively propagated biotypes: 9-19-1996 (si1), 9-24-1996 (si2), 9-341996 (si3) obtained from the Institute for Fruit Growing in Samokhvalovitchy from the E-2 breeding farm [13], and two biotypes 01-1999 (si0): 9-44-1996 (si4), and 9-84-1996 (si5) obtained from seeds of the 01-1999 (si0) biotype in 2005 . The comparison of the biotypes also included evaluation of the 01-1999 (si0) biotype, obtained from seeds originating from a shrub cultivated in Olsztyn from 1999. The plants were planted in Albic Luvisolx (Arenic) soil, deeply flattened, produced from clays of $\mathrm{pH}$ in $\mathrm{KCl} 6.8$ in $4 \times 2 \mathrm{~m}$ spacing. The shrubs started to fructify in the third year after planting.

The raw material was directly frozen in liquid nitrogen, and freeze-dried (24h; Christ Alpha 1-4 LSC; Germany). The homogeneous dry material was obtained by crushing the dried tissues using a closed laboratory mill (IKA A.11, Germany). The powders were kept in a refrigerator $\left(-80^{\circ} \mathrm{C}\right)$ until extract preparation.

\section{Determination of vitamin C, ash, fatty acids}

The total content of L-ascorbic acid was measured by PN90/A-75101/11 [14]. Determination of vitamin C by Tillmans method involves the reduction of a color solution of 2,6-dichlorophenolindophenol to a colorless substance under the influence of L-ascorbic acid. The amount of ash was tested by PN-90/A-75101 [15]. The principle of the method is to dry the sample to a constant mass under specified pressure, and temperature conditions, and to calculate the percentage of dry residue in the sample before drying. The total content of fatty acids was analyzed by PN-EN ISO 12966-1:2015-01 [16]. The principle of determination consists in subjecting the sample to fat esterification, and 
then separating the fatty acid methyl esters on the RTX 2330 column. The results of the analysis are expressed as a percentage of individual fatty acids.

\section{Determination of polyphenols}

Total polyphenols were determined by the Folin-Ciocalteau method [17]. An aliquot $(100 \mu \mathrm{L})$ of extract was mixed with $2000 \mu \mathrm{L}$ of distilled water, and $200 \mu \mathrm{L}$ of Folin-Ciocalteau reagent. Two hundred microliters of sodium carbonate solution $(200 \mathrm{~g} / \mathrm{L})$ was added to the mixture. The mixture was incubated at $20^{\circ} \mathrm{C}$ for $1 \mathrm{~h}$ in darkness. The absorbance was read at $765 \mathrm{~nm}$ on a UV-Vis spectrophotometer (Shimadzu UV-2401 PC, Kyoto, Japan). Solutions of gallic acid from 0 to $500 \mathrm{mg} / \mathrm{L}$ were measured with the same procedure as for the creation of the calibration curve. Total polyphenolics were expressed as $g$ of gallic acid equivalents (GAE) per $100 \mathrm{~g}$ of dry matter (d.m.).

\section{Determination of sugars and organic acids}

The chemical parameters, including organic acid contents, and sugar contents, were measured by the HPLC-RID method [18]. All determinations were performed in triplicate, and the results were expressed as g per $100 \mathrm{~g} \mathrm{~d} . \mathrm{m}$.

The sweetness, relative to sucrose was also determined:

Sweetness $=(1.5 \times$ fructose $)+(0.75 \times$ glucose $)+$ sucrose .

\section{Determination of antioxidant activity}

The DPPH, and FRAP assays were determined as previously described by Yen et al. [19], and Benzie and Strain [20], respectively. Determinations by DPPH, and FRAP methods were performed using a UV-2401 PC spectrophotometer (Shimadzu, Kyoto, Japan). All antioxidant activity analyses were done in triplicate, and expressed as micromoles of Trolox per $100 \mathrm{~g}$ d.m.

\section{Statistical analysis}

Statistical analysis, one-way ANOVA and principal component analysis (PCA) were conducted using Statistica version 12.5 (StatSoft, Kraków, Poland). Significant differences $(p \leq 0.05)$ between mean values were evaluated by one-way ANOVA, and Duncan's multiple range test.

\section{Results and discussion}

\section{Chemical compounds}

The tested new biotypes of cherry silverberry were determined for dry matter, vitamin $\mathrm{C}$, and ash (Table 1). The content of dry matter, mineral composition, and vitamin $\mathrm{C}$ of the cherry silverberry depends not only on the cultivars, biotypes or genotypes, but also on the growing conditions [21].

Table 1 concluded the amount of basic chemical parameters contained selected cherry silverberry of the examined biotypes. It was noted that the cherry silverberry biotypes differed in chemical contents. Kheiralipour et al. [22], and Zatylny et al. [23], found differences in the contents, and profile of chemical compounds from growing conditions, genetic differences, chemical composition of soil, the natural environmental as well as storage of maturity. It was shown that the examined cherry silverberry biotypes had a similar amount of dry matter. Among the tested new biotypes, the content of dry matter was low, and ranged from 19.81 in si0 to $27.16 \%$ in si1, and si5, respectively. The high content of water in cherry silverberry indicates the storage condition, and proper maturation. The water contents in this study were similar to the data reported $[5,13]$, in comparison with another berry such as chokeberry [24].

Table 1 shows that the content of vitamin $\mathrm{C}$ in the new examined biotypes of cherry silverberry had significant differences $(p<0.05)$ among the tested biotypes. The average contents of analyzed parameters was moderate

Table 1 Dry matter, vitamin C, ash, and sugar contents of new biotypes of cherry silverberry

\begin{tabular}{|c|c|c|c|c|c|c|}
\hline \multirow[t]{2}{*}{ Parameters } & \multicolumn{6}{|l|}{ Biotypes } \\
\hline & si0 & sil & si2 & si3 & si4 & si5 \\
\hline Dry matter (\%) & $19.81 \pm 0.02^{\mathrm{eA}, \mathrm{B}}$ & $27.16 \pm 0.02^{\mathrm{a}}$ & $25.07 \pm 0.02^{\mathrm{c}}$ & $25.51 \pm 0.02^{\mathrm{b}}$ & $24.27 \pm 0.02^{\mathrm{d}}$ & $27.16 \pm 0.02^{\mathrm{a}}$ \\
\hline Vitamin C (mg/100 g) & $15.13 \pm 0.00^{\mathrm{b}}$ & $14.87 \pm 0.00^{\mathrm{c}}$ & $17.60 \pm 0.01^{\mathrm{a}}$ & $14.31 \pm 0.00^{\mathrm{e}}$ & $14.10 \pm 0.00^{\mathrm{f}}$ & $14.77 \pm 0.00^{\mathrm{d}}$ \\
\hline Ash (\%) & $0.46 \pm 0.00^{\mathrm{d}}$ & $0.55 \pm 0.00^{\mathrm{c}}$ & $0.57 \pm 0.00^{\mathrm{b}}$ & $0.61 \pm 0.00^{\mathrm{a}}$ & $0.56 \pm 0.00^{c}$ & $0.62 \pm 0.00^{\mathrm{a}}$ \\
\hline Glucose (g/100 g d.m.) & $15.67 \pm 0.01^{\mathrm{f}}$ & $18.44 \pm 0.01^{\mathrm{e}}$ & $22.84 \pm 0.02^{\mathrm{a}}$ & $19.83 \pm 0.02^{\mathrm{d}}$ & $22.41 \pm 0.02^{b}$ & $21.27 \pm 0.02^{\mathrm{c}}$ \\
\hline Fructose (g/100 g d.m.) & $21.60 \pm 0.02^{\mathrm{f}}$ & $24.42 \pm 0.02^{\mathrm{e}}$ & $32.28 \pm 0.03^{\mathrm{a}}$ & $27.80 \pm 0.02^{\mathrm{d}}$ & $30.93 \pm 0.02^{b}$ & $30.27 \pm 0.02^{\mathrm{bc}}$ \\
\hline Total sugar (g/100 g d.m.) & $37.26 \pm 0.03^{\mathrm{f}}$ & $42.86 \pm 0.03^{\mathrm{e}}$ & $55.12 \pm 0.04^{\mathrm{a}}$ & $47.63 \pm 0.04^{\mathrm{d}}$ & $53.35 \pm 0.04^{b}$ & $51.54 \pm 0.04^{\mathrm{c}}$ \\
\hline Sweetness (g/100 g d.m.) & $39.70 \pm 0.12^{f}$ & $45.97 \pm 0.09^{\mathrm{e}}$ & $58.47 \pm 0.11^{\mathrm{a}}$ & $50.60 \pm 0.15^{\mathrm{d}}$ & $56.82 \pm 0.09^{b}$ & $54.61 \pm 0.13^{\mathrm{c}}$ \\
\hline
\end{tabular}

${ }^{\mathrm{A}}$ Values are mean \pm standard deviation. $n=3$

${ }^{\mathrm{B}}$ Means-SD followed by different letters within the same line represent significant differences $(p<0.05)$ 
$(15.13 \mathrm{mg} / 100 \mathrm{~g})$. The highest content of vitamin $\mathrm{C}$ in the new biotypes of cherry silverberry was obtained in si2 (>17 mg/100 g), while si1, si3, si4, si5 had the lowest amounts $(<15 \mathrm{mg} / 100 \mathrm{~g})$. Lower content of vitamin $\mathrm{C}$ was noted by Szałkiewicz and Kawecki [13], which ranged from 2.35 to $4.34 \mathrm{mg} / 100 \mathrm{~g}$, and by Bieniek et al. [5], which ranged from 4.22 to $7.70 \mathrm{mg} / 100 \mathrm{~g}$ compared with the present results; while the amount of ascorbic acid in the berry obtained in Ukraine [5], was similar, and its content ranged from 15.8 to $33.1 \mathrm{mg} / 100 \mathrm{~g}$. Khattak et al. [25] found that the berry contained $22 \mathrm{mg} / 100 \mathrm{~g}$ of vitamin C. However, the amount in Elaeagnus umbellate was 1.8 times higher compared with content in Elaeagnus multiflora [25]. Moreover, the content of vitamin $\mathrm{C}$ in cherry silverberry was 1.5 , and 4.0 times higher, and 2.0 times lower compared with amount in the saskatoon berry (Amelanchier alnifolia Nutt.), blueberry (Vaccinium spp.), and blackcurrant (Ribes nigrum), respectively [26, 27]. Generally, vitamin $C$ is very biologically active. It takes part in many extremely important reactions, and changes, stimulating various biochemical processes in the body. Vitamin C is the most well-known antioxidant. Thanks to its antioxidant properties, this vitamin has a protective role in heart, and blood vessel diseases [28, 29].

Among the researched parameters, ash was determined in the new studied biotypes of cherry silverberry (Table 1). The lowest content of ash compounds was noted in si0- $0.46 \%$, and the highest was found in si5-0.62\%. Moreover, the content of ash in cherry silverberry was 1.4 , and 2.5 times higher compared with the amount in the saskatoon berry (Amelanchier alnifolia Nutt.), and blueberry (Vaccinium spp.) [26]. Generally, the amount of mineral composition is determined by minerals such as calcium, magnesium, sodium, phosphorus as well as iron. These minerals occur in a form easily absorbed by the body [30].

\section{Determination of fatty acid profiles}

The content of fats was also determined in the cherry silverberry biotypes. Figure 1 illustrates the qualitative composition of fatty acid in cherry silverberry obtained from the investigated biotypes. There were six compounds of fatty acids found, and the major compounds included: palmitic acid (average $38 \%$ of total fatty acids) $>$ linoleic omega- 6 acid $(22 \%)>$ linoleic omega- 3 acid $(18 \%) \geq$ oleic and stearic acid $(8 \%$ each) $>$ palmitoleic acid $(<1 \%)$. The total fatty acids content ranged between 75.61 in the si4 to $96.15 \mathrm{~g} / 100 \mathrm{~g}$ in the si3. Thus, the average fatty acids was $89 \mathrm{~g} / 100 \mathrm{~g}$, and was 1.2 times lower than the amount in biotype si0. Piłat et al. [31], reported that the total contents of lipids in cherry silverberry was $1.4 \mathrm{~g} / 100 \mathrm{~g}$ of pulp, while the amount, and profile of fatty acids in the berry obtained by Bieniek et al. [5], were similar. Palmitic acid was the predominant fatty acids in the chemical compositions, and ranged from 30.52 in the si4 to $40.01 \mathrm{~g} / 100 \mathrm{~g}$ in the si3. In turn, linoleic omega- 6 , and omega- 3 ( $\alpha$-linolenic acid) were the next fractions in the studied cherry silverberry biotypes. According to nutritionists, the fatty acids ratio of omega-6 to omega-3 should vary from 1:1 to 5:1; in turn, in the cherry silverberry, the ratio ranged from 1:1.2 to $2: 1$ [5]. Linoleic acid, and linolenic acid are two of the essential unsaturated fatty acids (PUFAs). Since PUFAs are constituents of tissues, they must be delivered in food. Regardless of the structural role of PUFAs, they play an important role in the synthesis of certain biologically active substances and participate in the regulation of many important system
Fig. 1 Fatty acid profiles, and contents of new biotypes of cherry silverberry (g/100 g d.m.). Values are mean \pm standard deviation. $n=3$

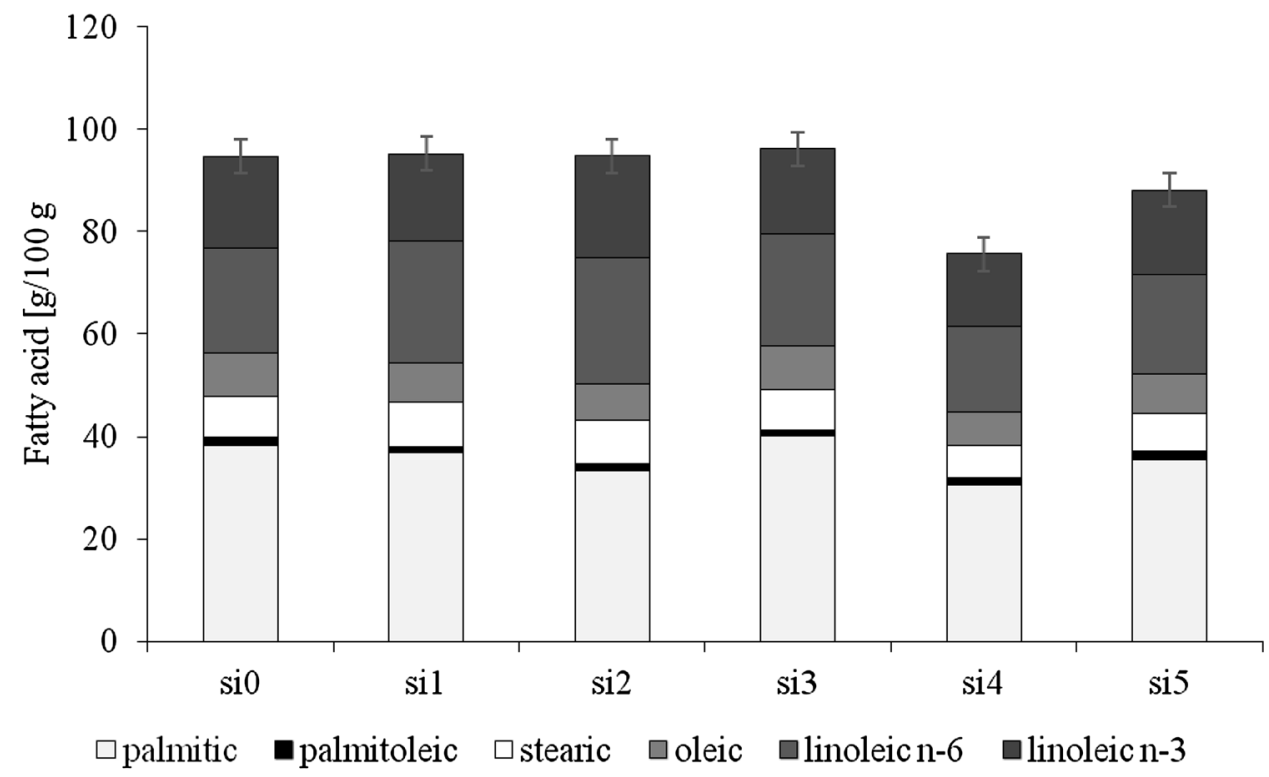


functions. They are substrates for the synthesis of prostaglandins and multi-acting hormones [32]. The average contents of these compounds was 21.18 , and $16.98 \mathrm{~g} / 100 \mathrm{~g}$, and also depended on the biotypes $(p<0.05)$. The smallest fraction of fatty acids corresponded to oleic, and stearic acid, and the average content was $7.72 \mathrm{~g} / 100 \mathrm{~g}$, which was 5.4 times higher than in palmitoleic acid.

\section{Determination of organics acid, and sugars}

The basic chemical, and quality components of fruits affecting their acceptance by the human body include the contents of sugars, acids, and their respective ratios. These components determine the sweetness of fruits. Table 1 gives the quantitative, and qualitative composition of sugars and sweetness in cherry silverberry biotypes. There were two sugars, glucose, and fructose biotypes noted. The total average contents of sugars was between 37.26, and $55.12 \mathrm{~g} / 100 \mathrm{~g} \mathrm{d.m}$., and the biotypes differed significantly $(p<0.05)$ in these compounds. The lowest amount of analyzed sugars in the new biotypes of cherry silverberry was si0 ( $<38 \mathrm{~g} / 100 \mathrm{~g} \mathrm{~d}$.m.), while the highest contents of these contents were determined in the si2, si4, si5 ( $>50 \mathrm{~g} / 100 \mathrm{~g}$ d.m.). The fructose was predominantly sugars of tested fruits, and accounted for $57-59 \%$ of all sugars. In turn, glucose was the second fraction, and accounted for $41-43 \%$ and was 1.4 times lower, on average, than the glucose content. The sweetness in cherry silverberry averaged $51 \mathrm{~g} / 100 \mathrm{~g}$ d.m.; while in the sweet cherry, it ranged from 9.33 to $19.08 \mathrm{~g} / 100 \mathrm{~g}$ fresh matter, and the sweetness in cherry silverberry was 2.6 times higher compared with sweet cherry. It is very difficult to compare a dry mass to a fresh mass because, during the freeze drying of fruits, the parameters in fruit tissues are more concentrated. Thus, the results received in dry tissues are normally higher than in fruits marked in fresh matter [33]. Bieniek et al. [5], reported that the contents of total sugars in cherry silverberry fruits was between 5.34, and $6.30 \%$, and was five times lower than fruits in the current study. In turn, the wine prepared from cherry silverberry, fructose was predominantly sugars, and contained $0.42 \mathrm{~g} / \mathrm{L}$; while the amount of glucose was five times lower [34]. Moreover, the contents of sugars in cherry silverberry was 3.6, and 5.0 times higher, and similar content compared with amount in goji, saskatoon berry, and pear (Pyrus communis L.), respectively [28, 35, 36].

Figure 2 showed the profile, and content of organic acids in the new biotypes of cherry silverberry, and presented significant differences $(p<0.05)$ among the content of sugars, and organic acids-tested biotypes. In addition, at the times of the increase in the content of sugars, a lower content of acids in individual biotypes was noted. The organic acids content ranged from 18.48 to $34.11 \mathrm{~g} / 100 \mathrm{~g}$ d.m. The cherry silverberry biotype with the highest content of tested organic acids was si0 (> $30 \mathrm{~g} / 100 \mathrm{~g} \mathrm{d.m}$.), while si1, and si2 had the lowest contents of organic acids ( $<20 \mathrm{~g} / 100 \mathrm{~g} \mathrm{~d}$.m.). There were seven compounds of organic acids found, and the major ones were malic, quinic, and tartaric acid in the cherry silverberry biotypes. These compounds accounted for $55-60 \%, 11-15 \%$, and $9-18 \%$, respectively, of all organic acids contents. The content of malic acid in cherry silverberry biotypes ranged
Fig. 2 Organic acids profiles, and contents of new biotypes of cherry silverberry (g/100 g d.m.). Values are mean \pm standard deviation. $n=3$

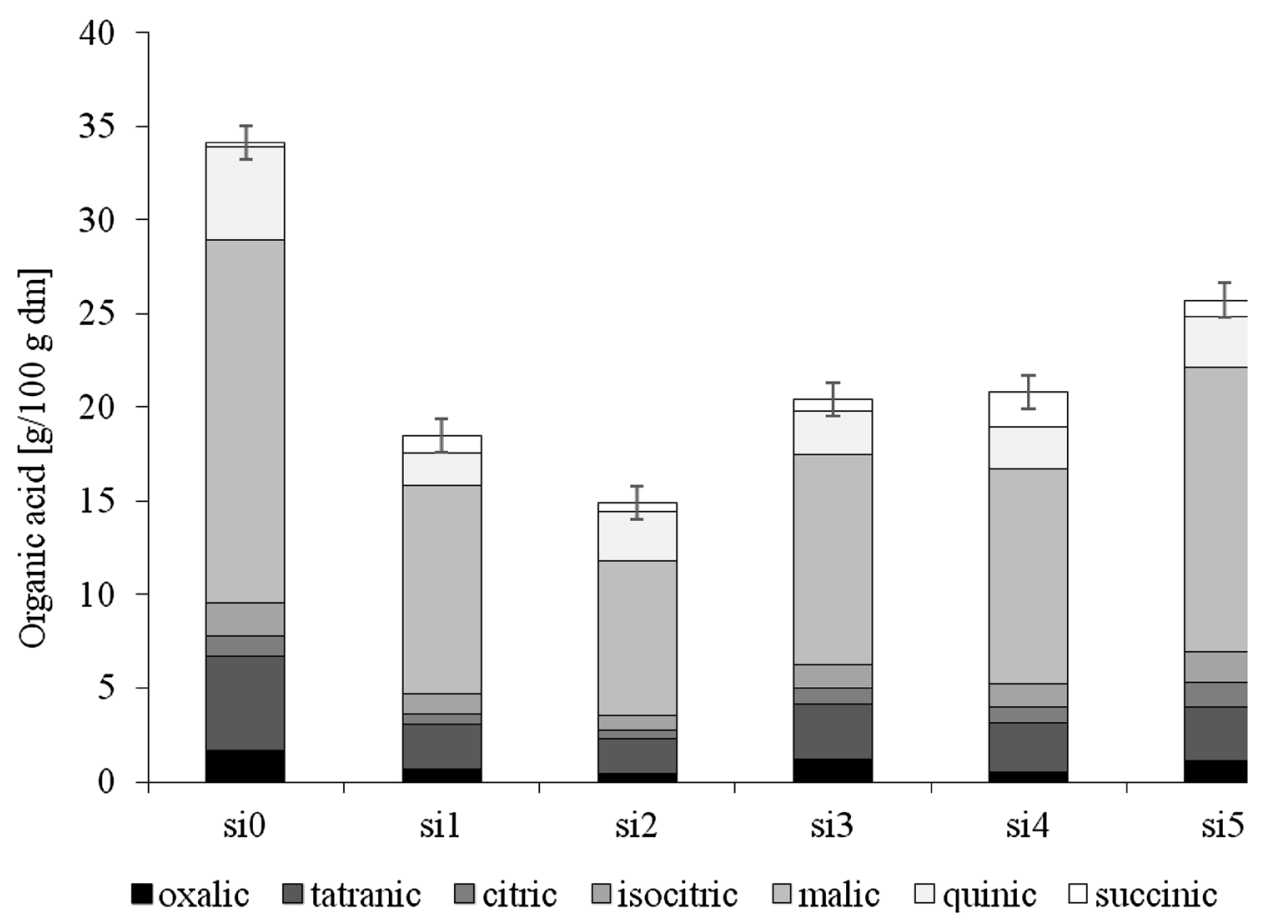


from 8.27 to $19.34 \mathrm{~g} / 100 \mathrm{~g}$ d.m., tartaric acid ranged from 1.90 to $4.97 \mathrm{~g} / 100 \mathrm{~g} \mathrm{~d}$.m., and quinic acid ranged from 1.75 to $4.95 \mathrm{~g} / 100 \mathrm{~g}$ d.m. The other analyzed compounds, such as oxalic, citric, isocitric, and succinic, were found in trace amounts. According to Nawirska-Olszańska et al. [37], the average content of organic acids in sweet cherry was 1.6 times lower than the average content in cherry silverberry. In turn, malic acid was also predominant among the identified organic acids in sweet cherry [34, 37]. Bieniek et al. [5], reported that the content of total organic acids ranged from 0.78 to $1.20 \%$, and was 11 times lower than the current results. Wasiuk et al. [24], noted that the amount of total acidity was $1.4-2.3 \%$ in cherry silverberry genotypes grown in Ukraine, while Szałkiewicz and Kawecki [13] found that acids ranged from 2.14 to $2.52 \%$ in several forms of these fruits cultivated in Belarus. However, the wines of cherry silverberry fruits contains $2.59 \mathrm{~g} / \mathrm{L}$ of citric acid, $2.16 \mathrm{~g} / \mathrm{L}$ of succinic acid, and $3.08 \mathrm{~g} / \mathrm{L}$ of oxalic acid, but the predominant acid was lactic acid (7.32 g/L) [34]. In addition, the ratio between sugars, and acids ranged from 1.09 (si0) to 3.70 (si2), which was lower than in other cherry silverberry cultivars [5].

The study of sugars, and organic acids in food, especially berries, are very important. Their contents, and the ratio given can affect the sensorial, and chemical characteristics of the matrix inter alia: total acidity, $\mathrm{pH}$, degree of sweetness, microbial stability as well as global acceptability. It can also provide valuable information on pro-healthy food, and/or on how to optimize methods of selected technological processes [38].

\section{Determination of polyphenolic compounds}

The polyphenolic compounds contents in selected cherry silverberry biotypes was illustrated in Fig. 3. The total polyphenolic compounds contents ranged from $3.20 \mathrm{~g}$ GAE $/ 100 \mathrm{~g}$ d.m. to $9.20 \mathrm{~g} \mathrm{GAE} / 100 \mathrm{~g} \mathrm{~d} . \mathrm{m}$., in the si2, and in si0, respectively. The polyphenol contents in wines prepared from cherry silverberry averaged $0.51 \mathrm{~g} \mathrm{GAE} / 100 \mathrm{~mL}$. The differences may result from the variety, species, growing conditions, extraction method, technological process or analyzed materials [34]. However, the contents of total polyphenolic compounds in the Elaeagnus umbellata fruits was three times lower than the contents of these compounds in Elaeagnus multiflora [25]. In turn, the polyphenol contents in sweet cherry was six times lower than cherry silverberry [37].

The study of polyphenolic compounds in food, especially berries, are very important. Polyphenolic compounds, commonly found in vegetable raw materials, are classified as secondary metabolites. As a dietary component, polyphenols play an important role in shaping the sensory characteristics of food. They give food a specific tart, and bitter taste, and are responsible for its color and fibrousness. Polyphenols are one of the most important natural antioxidants with a strong scavenging ability of free radicals; they also show anticancer, as well as anti-ulcer properties. In turn, the composition of the phenolics fraction of fruits, and vegetables depends on some factors such as species, variety, climatic, and agrotechnical conditions [30, 39].

\section{Antioxidant activity}

Figure 4 presents antioxidant activity determined by DPPH, and FRAP assay. A statistical analysis illustrated that the examined cherry silverberry biotypes differed in their antioxidant activity $(p<0.005)$. The antioxidant activity in cherry silverberry depended on the biotypes. Antioxidant activity of the tested cherry silverberry biotypes ranged from $4.32 \mathrm{mM}$ TE/100 $\mathrm{g}$ in the si4 to $9.49 \mathrm{mM}$ TE/100 $\mathrm{g}$
Fig. 3 Polyphenolic compounds content of new biotypes of cherry silverberry (g GAE/100 g d.m.). Values are mean \pm standard deviation. $n=3$

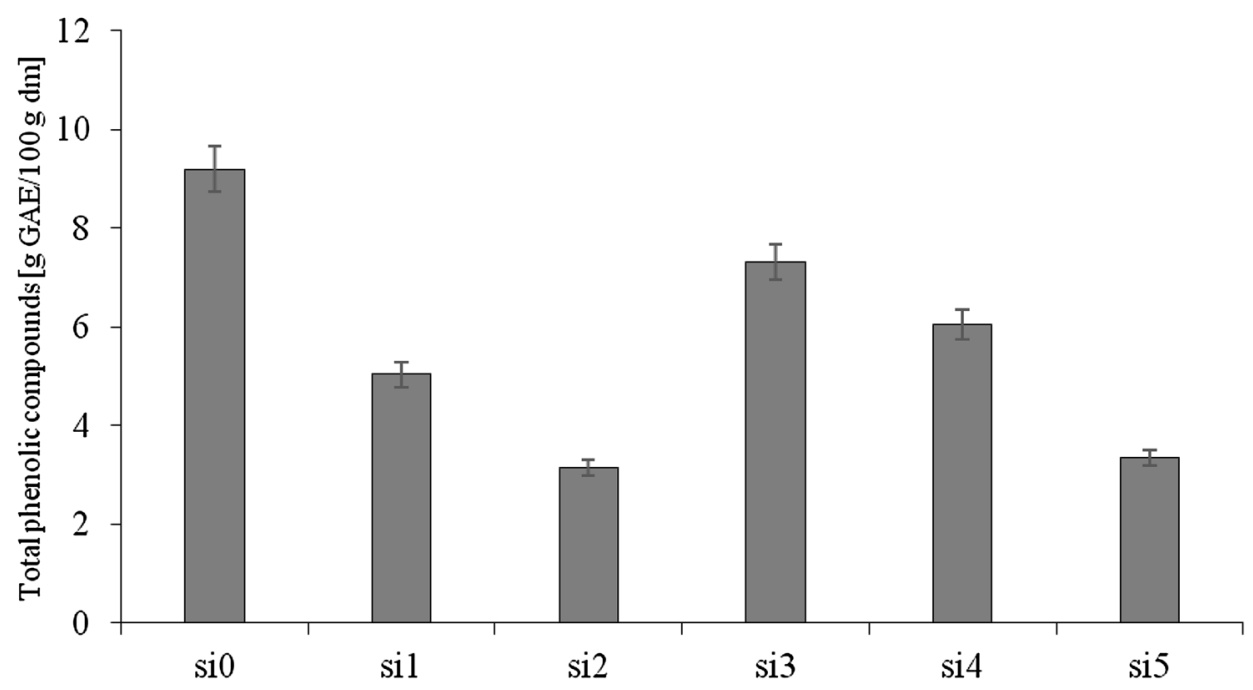


Fig. 4 Antioxidant activity of new biotypes of cherry silverberry (mmol TE/100 g d.m.). Values are mean \pm standard deviation. $n=3$

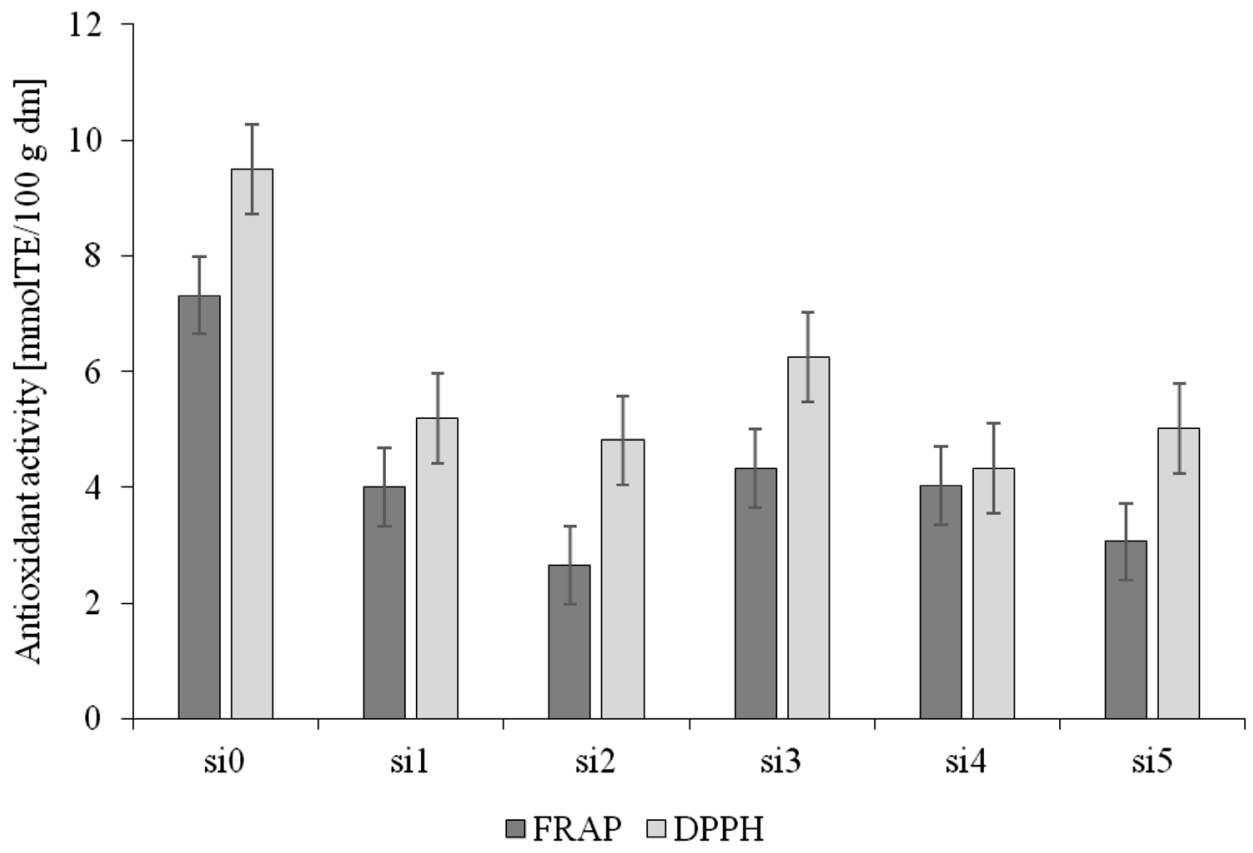

d.m. in the si0 measured using DPPH assay; from $2.65 \mathrm{mM}$ $\mathrm{TE} / 100 \mathrm{~g}$ in the $\mathrm{si} 2$ to $7.32 \mathrm{mM} \mathrm{TE} / 100 \mathrm{~g} \mathrm{~d} . \mathrm{m}$. in the si0, determined using the FRAP solution. However, the average antioxidant activity tested by DPPH, and FRAP assay was 5.11, and $3.62 \mathrm{mM} \mathrm{TE} / 100 \mathrm{~g} \mathrm{d.m.,} \mathrm{respectively,} \mathrm{and} \mathrm{was}$ 1.8 , and 2.0 times lower than the volume in biotype si0. The antioxidant activity [DPPH assay] in other cherry silverberry species (Elaeagnus umbellata) was 1.2 times higher than in
Elaeagnus multiflora [25], while the antioxidant activity of the wines was around 2.6 times lower [34]. The antioxidant capacity measured by a FRAP assay was 3.4 times higher in cherry silverberry compared to sweet cherry [37].
Fig. 5 PCA map showing the relationship among chemical compositions, and antioxidant activity of of cherry silverberry

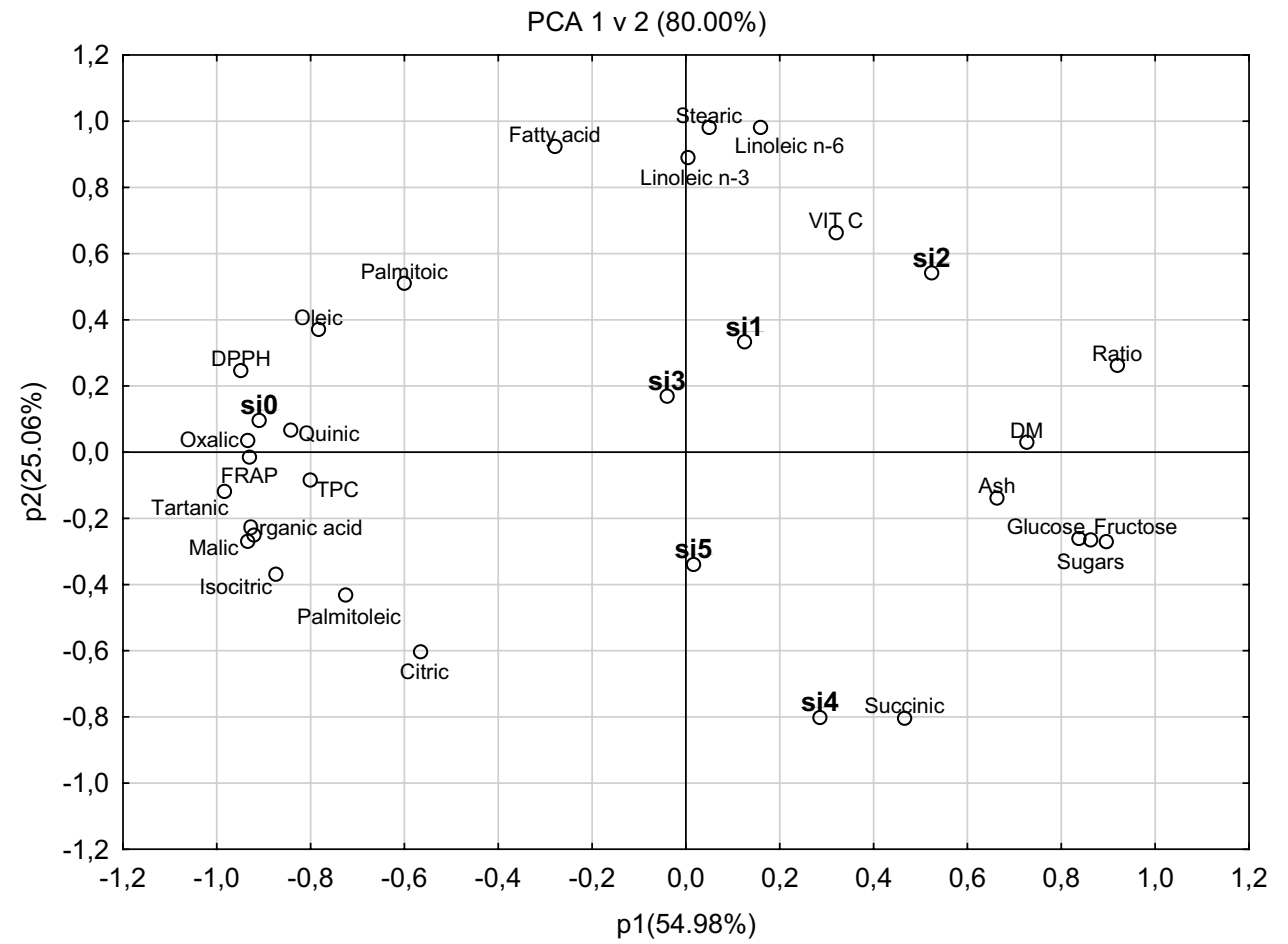




\section{Principal component analysis (PCA)}

The examined results were subjected to a principal component analysis (Fig. 5). The resulting data determined the relationship between antioxidant activity, and chemical compounds such as vitamin $\mathrm{C}$, ash, organic acids, sugars, and polyphenols of new studied cherry silverberry biotypes (Fig. 5). The PCA illustrated $80.00 \%$ of the overall data variation, and the first (PC1), and second (PC2) factors explained $54.98 \%$, and $25.06 \%$ of the data variation, respectively. The PC1 factor is clearly comprised of ash, sugars (glucose, and fructose), the ratio between sugars, and organic acids, vitamin $\mathrm{C}$, linoleic, and $\alpha$-linoleic acids as well as succinic acid. However, the PC2 factor is connected mainly with organic acids, total phenolic compounds, antioxidant activity, and other fatty acids. Some new biotypes (e.g., si1, and si2) were a good source of vitamin C, linoleic, and $\alpha$-linoleic acids, which was confirmed by the positive correlation of PC1. However, the si5, and si4 biotypes of cherry silverberry were rich in ash, glucose, fructose, and succinic acid. The new biotypes, si0, and si3 of cherry silverberry, showed the highest antioxidant activity (DPPH), fatty acids (palmitoleic, oleic acids), oxalic, and quinic acids. The si0 biotypes showed higher contents of total polyphenolic compounds, organic acid (including tartanic, malic, isocitric), palmitoleic acid, and higher antioxidant activity (FRAP) than the other tested biotypes.

\section{Conclusions}

In summary, the examined new biotypes of cherry silverberry fruits had significantly different chemical compositions, and antioxidant activity. The principal component analysis confirmed significant disparity in the phytochemical components of cherry silverberry depending on biotypes. Some new biotypes contain a high content of vitamin C, linoleic omega-6, $\alpha$-linoleic acids (si1, and si2), glucose, fructose, ash (si5, and si4), other fatty acids, organic acids, and antioxidant activity (si0, and si3). In addition, the si0 biotypes also showed a high content of total polyphenolic compounds, organic acids (including tartanic, malic, isocitric), and palmitoleic acid, as well as higher antioxidant activity than other tested biotypes. The following average contents were recorded: polyphenols— $5.68 \mathrm{~g} \mathrm{GAE} / 100 \mathrm{~g} \mathrm{~d}$.m., vita$\min \mathrm{C}-15.13 \mathrm{mg} / 100 \mathrm{~g}$, ash $-0.56 \%$, fatty acids $-89.99 \%$, organic acids-22.41 g/100 g d.m., sugars—47.96 g/100 g d.m., and antioxidant activity-3.62 (FRAP assay), and $5.11 \mathrm{mM}$ TE/100 g d.m. (DPPH assay). The new examined biotypes of cherry silverberry cultivated in Poland are interesting material, and may be a good source for the production of functional foods, and direct consumption. Moreover, the fruit grows well in temperate climates, which may be important for fruit cultivation.

Acknowledgements Publication supported by Wroclaw Centre of Biotechnology, the Leading National Research Centre (KNOW) program for 2014-2018. Project financially supported by Minister of Science, and Higher Education in the range of the program entitled "Regional Initiative of Excellence" for the years 2019-2022, Project no. 010/ RID/2018/19, amount of funding 12.000.000 PLN.

\section{Compliance with ethics standards}

Conflict of interest The authors declare no conflict of interest.

Compliance with ethics requirements This article does not contain any studies with human, and animal subjects.

Open Access This article is distributed under the terms of the Creative Commons Attribution 4.0 International License (http://creativeco mmons.org/licenses/by/4.0/), which permits unrestricted use, distribution, and reproduction in any medium, provided you give appropriate credit to the original author(s) and the source, provide a link to the Creative Commons license, and indicate if changes were made.

\section{References}

1. Bieniek A, Dragańska E, Prancketis V (2016) Assessment of climatic conditions for Actinidia arguta cultivation in north-eastern Poland. Zemdirb Agric 103(3):311-318

2. Patel S (2015) Plant genus Elaeagnus: underutilized lycopene and linoleic acid reserve with permaculture potential. Fruit 70(4):191-199

3. Tehranizadeh ZA, Baratian A, Hosseinzadeh H (2016) Russian olive (Elaeagnus angustifolia) as herbal healer. Bioimpact 6(3):155-167

4. Lee JH, Seo WT, Cho KM (2011) Determination of phytochemical contents and biological activities from the fruits of Elaeagnus multiflora. J Food Sci Nutri 16:29-36

5. Bieniek A, Piłat B, Szałkiewicz M, Markuszewski B, Gojło E (2017) Evaluation of yield, morphology and quality of fruits of cherry silverberry (Elaeagnus multiflora Thunb.) biotypes under conditions of north-eastern Poland. Pol J Nat Sci 32(1):61-70

6. Ahmadiani A, Hosseiny J, Semnanian S, Javan M, Saeedi F, Kamalinejad M, Saremi S (2000) Antinociceptive and antiinflammatory effects of Elaeagnus angustifolia fruit extract. J Ethnopharmacol 72:287-292

7. Bieniek A, Kawecki Z, Piotrowicz-Cieślak A (2002) The content of some organic ingredients in the fruit of less known fruit plants. Biul Nauk 14:11-17 (in Polish)

8. Sakamura F, Suga T (1987) Changes in chemical components of ripening of oleaster fruits. Phytochem 26(9):2481-2484

9. Cansev A, Sahan Y, Celik G, Taskesen S, Ozbey H (2011) Chemical properties and antioxidant capacity of Elaeagnus angustifolia L. fruits. Asia J Chem 23(6):2661-2665

10. Rop O, Mleek J, Jurikova T, Valsikova M, Sochor J, Reznicek V, Kramarova D (2010) Phenolic content, antioxidant capacity, radical oxygen species scavenging and lipid peroxidation inhibiting activities of extracts of five black chokeberry (Aronia melanocarpa (Michx.) Elliot) cultivars. J Med Plants Res 4:2431-2437

11. de Kok TM, van Breda SG, Manson MM (2008) Mechanisms of combined action of different chemopreventive dietary compounds: a review. Eur J Nutr 47(Suppl. 2):51-59 
12. Dzidek K, Kopeć A, Tabaszewska M (2019) Potential of sweet cherry (Prunus avium L.) by-products: bioactive compounds and antioxidant activity of leaves and petioles. Eur Food Res Technol 245:763-772

13. Szałkiewicz M, Kawecki Z (2003) Oliwnik wielokwiatowy (Elaeagnus multiflora Thunb.)-nowa roślina sadownicza. Biul Nauk 22:285-290 (in Polish)

14. PN-90/A-75101/11 (Determination of vitamin C content)

15. PN-90/A-75101 (Determination of ash content)

16. PN-EN ISO 12966-1:2015-01 (Determination of fatty acids content)

17. Xianggun G, Ohlander M, Jeppson N, Bjork L (2000) Changes in antioxidant effects and their relationship to phytonutrients in fruits of sea buckthorn during maturation. J Agric Food Chem 48:1485-1490

18. Kapusta I, Cebulak T, Oszmiański J (2018) Characterization of polish wines produced from the interspecific hybrid grapes grown in south-east Poland. Eur Food Res Technol 244(3):441-455

19. Yen GC, Chen HY (1995) Antioxidant activity of various tea extracts in relation to their antimutagenicity. J Agric Food Chem 43:27-32

20. Benzie IF, Strain JJ (1996) The ferric reducing ability of plasma (FRAP) as a measure of "antioxidant power": the FRAP assay. Anal Biochem 239(1):70-76

21. Park YS, Namiesnik J, Vearasilp K, Leontowicz H, Leontowicz M, Barasch D D et al (2014) Bioactive compounds and the antioxidant capacity in new kiwi fruit cultivars. Food Chem 165:354-361

22. Kheiralipour K, Tabatabaeefar A, Mobli H, Rafiee S, Sahraroo A, Rajabipour A, Jafari A (2008) Some physical properties of apple. Pak J Nut 7(5):667-672

23. Zatylny AM, Ziehl WD, St-Pierre RG (2005) Physicochemical properties of fruit of chokecherry (Prunus virginiana L.), highbush cranberry (Viburnum trilobum Marsh.), and black currant (Ribes nigrum L.) cultivars grown in Saskatchewan. Can J Plant Sci 85(2):425-429

24. Oszmiański J, Lachowicz S (2016) Effect of the production of dried fruits and juice from chokeberry (Aronia melanocarpa L.) on the content and antioxidative activity of bioactive compounds. Molecule 21(8): 1098

25. Khattak KF (2012) Free radical scavenging activity, phytochemical composition and nutrient analysis of Elaeagnus umbellata berry. J Medic Plants Res 6(39):5196-5203

26. Mazza G (2005) Compositional and functional properties of saskatoon berry and blueberry. Int J Fruit Sci. 5(3):101-120

27. Mattila PH, Hellström J, McDougall G, Dobson G, Pihlava JM, Tiirikka T et al (2011) Polyphenol and vitamin C contents in European commercial blackcurrant juice products. Food Chem 127(3):1216-1223

28. Yew WW, Chang KC, Leung CC, Chan DP, Zhang Y (2018) vitamin $\mathrm{C}$ and Mycobacterium tuberculosis persisters. Ant Agents Chemotherapy 62(11):e01641-18
29. Li W, Qiang M, Dong T, Li H (2018) Role of vitamin C in skin diseases. Front Physiol 9:819

30. Lachowicz S, Oszmiański J, Seliga Ł, Pluta S (2017) Phytochemical composition and antioxidant capacity of seven saskatoon berry (Amelanchier alnifolia Nutt.) genotypes grown in Poland. Molecule 22(5):853

31. Piłat B, Zadernowski R, Czaplicki S (2013) Trends in the technology of fruits, vegetables and mushrooms. Characteristics of the olives fruit. In: VI national scientific conference of processors of fruit and vegetables, Rogów 16-17 of maj, E-poster, book after conference, $\mathrm{p} 42$ (in Polish)

32. Minkowski K, Grzeskiewicz S, Jerzewska M (2011) Evaluation of the nutritional value of vegetable oils with a high content of linolenic acids based on the composition of fatty acids, tocopherols and sterols. Food Sci Technol Qual 18(2):79-92 (in Polish)

33. Arzani K, Khoshghalb H, Malakouti MJ, Barzegar M (2008) Postharvest fruit physicochemical changes and properties of Asian (Pyrus serotina Rehd.) and European (Pyrus communis L.) pear cultivars. Hortic Environ Biotechnol 49(1):244-252

34. Cho KM, Joo OS (2014) Quality and antioxidant characteristics of Elaeagnus multiflora wine through the thermal processing of juice. Korean J Food Preserv 21(2):206-214

35. Montesano D, Cossignani L, Giua L, Urbani E, Simonetti MS, Blasi F (2016) A simple HPLC-ELSD method for sugar analysis in goji berry. J Chem 2016:6271808. https://doi. org/10.1155/2016/6271808

36. Kolniak-Ostek J (2016) Chemical composition and antioxidant capacity of different anatomical parts of pear (Pyrus communis L.). Food Chem 203:491-497

37. Nawirska-Olszańska A, Kolniak-Ostek J, Oziembłowski M, Ticha A, Hyšpler R, Zadak Z et al (2017) Comparison of old cherry cultivars grown in Czech Republic by chemical composition and bioactive compounds. Food Chem 228:136-142

38. Chinnici F, Spinabelli U, Riponi C, Amati A (2005) Optimization of the determination of organic acids and sugars in fruit juices by ion-exclusion liquid chromatography. J Food Comp Anal 18(2-3):121-130

39. Kosiorek A, Oszmiański J, Golański J (2013) Basics for the use of plant polyphenols as nutraceuticals with antiplatelet properties. Post Fitoter 2:108-117 (in Polish)

Publisher's Note Springer Nature remains neutral with regard to jurisdictional claims in published maps and institutional affiliations. 